ISSN 1980 - 6477

Journal homepage: www.abms.org.br/site/paginas

Rafael André Mergener ${ }^{1}$; Luis Sangoi ${ }^{2}$ and Antonio Eduardo Coelho ${ }^{2}(\bowtie)$

${ }^{1}$ Universidade do Oeste de Santa Catarina

E-mail: rafael.mergener@unoesc.edu.br

${ }^{2}$ Universidade do Estado de Santa Catarina E-mail: luis.sangoi@udesc.br, coelhoagro7@gmail.com.

$\checkmark$ Corresponding author

How to cite

MERGENER, R. A.; SANGOI, L.; COELHO, A. E. Nitrogen source does not change the morphophysiological characteristics of maize on a clay soil. Revista Brasileira de Milho e Sorgo, v. 20, e1220, 2021.

\section{NITROGEN SOURCE DOES NOT CHANGE THE MORPHOPHYSIOLOGICAL CHARACTERISTICS OF MAIZE ON A CLAY SOIL}

\begin{abstract}
This study aimed to evaluate the effect of different nitrogen fertilizer sources and rates on the morphophysiological characteristics and nitrogen use efficiency of maize. The experiment was set in Campos Novos, Santa Catarina State, Brazil, during the 2016/2017 and 2017/2018 growing seasons. The experimental design was a randomized block with treatments arranged in split plots. Four nitrogen sources were evaluated in the main plots: conventional urea, protected urea, nitrification inhibitor-treated urea, and urease inhibitor-treated urea. Four nitrogen rates were assessed in the split plots: 0 (control), 140, 280, and 420 $\mathrm{kg} \mathrm{N} \mathrm{ha}^{-1}$. Nitrogen source did not affect ear height, leaf area index, stem diameter, or number of senescent leaves. Increments in nitrogen rate increased plant height, ear height, stem diameter, and grain nitrogen content but decreased nitrogen use efficiency. Stabilized (nitrification/urease inhibitor-treated) or protected $\mathrm{N}$ sources did not influence morphophysiological characteristics or improve nitrogen use efficiency of maize compared with conventional urea.
\end{abstract}

Keywords: Zea mays, Nitrogen fertilizers, Urea, Leaf area, Nitrogen use efficiency.

\section{A FONTE DE NITROGÊNIO NÃO ALTERA CARATERÍSTICAS MORFOFISIOLÓGICAS DO MILHO NUM SOLO ARGILOSO}

Resumo - Este trabalho foi conduzido com objetivo de avaliar o efeito de fontes e doses de nitrogênio $(\mathrm{N})$ sobre características morfofisiológicas e a eficiência agronômica de uso do $\mathrm{N}$ do milho. $\mathrm{O}$ experimento foi conduzido a campo, no município de Campos Novos, SC, durante as safras de 2016/17 e 2017/18. O delineamento experimental foi de blocos ao acaso, dispostos em parcelas subdivididas. Na parcela principal foram testadas quatro fontes de $\mathrm{N}$ : ureia convencional, ureia protegida, ureia com inibidor de nitrificação e ureia com inibidor de uréase. Nas subparcelas foram avaliadas quatro doses de N: 0, 140,280 e $420 \mathrm{~kg}$ de $\mathrm{N} \mathrm{ha}^{-1}$. As fontes de $\mathrm{N}$ não afetaram a altura de inserção de espiga, o índice de área foliar, o número de folhas senescidas e o diâmetro do colmo da cultura. O incremento da dose de $\mathrm{N}$ aumentou a altura de plantas, a altura de inserção de espigas, o diâmetro do colmo e o teor de $\mathrm{N}$ nos grãos, mas reduziu a eficiência agronômica de uso do nitrogênio. A utilização de fontes estabilizadas (com inibidor de nitrificação/uréase) e protegidas de $\mathrm{N}$ não alterou significativamente as características morfofisiológicas do milho e nem aumentou a eficiência agronômica de uso do nitrogênio, em relação à ureia convencional.

Palavras-chave: Zea mays, Fertilizantes nitrogenados, Ureia, Área foliar, Eficiência uso do nitrogênio. 
Nitrogen $(\mathrm{N})$ is fundamental for plant growth. It is the most absorbed mineral nutrient by maize (Fageria \& Baligar, 2005). $\mathrm{N}$ is part of cellular components that are essential for maize development. This chemical element makes up 78\% of all atmospheric gases. Despite the abundance of $\mathrm{N}_{2}$ molecules, $\mathrm{N}$ is not directly available to plants. For absorption by plant roots, $\mathrm{N}$ must be available in the form of ammonium $\left(\mathrm{NH}_{4}^{+}\right)$or nitrate $\left(\mathrm{NO}_{3}^{-}\right)$ (Daryanto et al., 2019).

Supply of $\mathrm{N}$ to maize directly impacts morphophysiological characteristics of plants by influencing growth patterns (Coelho et al., 2020). The major morphological changes include increments in plant height, ear height, and stem diameter, traits that are directly related to lodging (Coelho et al., 2019). Leaf area and relative chlorophyll content are strictly correlated with the efficiency of radiation interception and use and are also influenced by $\mathrm{N}$ availability, thereby affecting the productive potential of maize (Coelho et al., 2020). Soil $\mathrm{N}$ availability is affected by $\mathrm{N}$ losses, potentially leading to negative effects on morphophysiological characteristics.

Soil $\mathrm{N}$ can be lost through leaching or volatilization. Leaching consists of the vertical movement of $\mathrm{NO}_{3}^{-}$molecules in soil to depths that are unavailable to roots (De Notaris et al., 2018). Volatilization is the loss of $\mathrm{N}$ from $\mathrm{NH}_{3}^{+}$, which is highly volatile (Cantarella et al., 2018). The source of $\mathrm{N}$ fertilizer influences the magnitude of $\mathrm{N}$ losses, affecting $\mathrm{N}$ use efficiency, a fact that must be considered when selecting $\mathrm{N}$ source and rate (Cantarella et al., 2018).

Urea is the most common $\mathrm{N}$ fertilizer because of its high $\mathrm{N}$ concentration (44-46\%), low cost per $\mathrm{kg}$ of $\mathrm{N}$ applied, and ease of application. Urea also has high solubility, which promotes $\mathrm{N}$ availability and absorption by plant roots. The main disadvantage of conventional urea is its high susceptibility to ammonia $\left(\mathrm{NH}_{3}^{+}\right)$volatilization. This effect is even stronger when urea is applied to the soil surface under high temperature and low soil moisture conditions (Sangoi et al., 2016).

One of the alternatives to reduce $\mathrm{N}$ losses and optimize agronomic $\mathrm{N}$ use efficiency is to use stabilized $\mathrm{N}$ fertilizer sources, containing urease or nitrification inhibitors. Urease inhibitors reduce $\mathrm{N}$ losses by volatilization (Lana et al., 2018), whereas nitrification inhibitors mitigate nitrate leaching in soil (Migliorati et al., 2014). Another option is to use fertilizers that have a protective coating surrounding urea granules, simultaneously minimizing losses by leaching and volatilization (Prando et al., 2012). These stabilized and protected $\mathrm{N}$ sources have been recently made available commercially. Studies on the effects of these $\mathrm{N}$ sources on maize have focused on $\mathrm{N}$ losses and crop yield, with little emphasis on morphophysiological parameters.

This study tested the hypotheses that (i) $\mathrm{N}$ sources that minimize $\mathrm{N}$ losses alter the morphophysiological parameters of maize by promoting greater $\mathrm{N}$ availability throughout the crop cycle compared with conventional urea and (ii) morphophysiological changes in maize caused by the use of sources that minimize $\mathrm{N}$ losses increase the use efficiency of this nutrient. The objective was to investigate the effects of different sources and rates of $\mathrm{N}$ fertilizers on the morphophysiological characteristics and $\mathrm{N}$ use efficiency of maize.

\section{Material and methods}

The experiment was set in Campos Novos, midwest region of Santa Catarina State, Brazil, during the 2016/2017 and 2017/2018 growing seasons. 
The experimental site is located at geographical coordinates $27^{\circ} 24^{\prime} 0^{\prime \prime} \mathrm{S} 51^{\circ} 13^{\prime} 30^{\prime \prime} \mathrm{W}$ and $934 \mathrm{~m}$ above sea level. The climate is classified as temperate $(\mathrm{Cfb}$ type in Köeppen's classification system). The soil of the experimental site is a Dystrophic Red Nitosol. Meteorological data (average temperatures and rainfall) for the study period are presented in Figure 1. The $0-20 \mathrm{~cm}$ soil layer was analyzed in August 2016 according to methods recommended by the Soil Chemistry and Fertility Commission of Rio Grande do Sul and Santa Catarina States (CQFS RS/SC, 2016). The soil presented the following characteristics: $60 \%$ clay, $\mathrm{pH}\left(\mathrm{H}_{2} \mathrm{O}\right)$ 5.6, SMP index 5.6, 3.8\% organic matter, $21.3 \mathrm{cmol}_{\mathrm{c}} \mathrm{dm}^{-3}$ cation-exchange capacity $(\mathrm{pH}$ 7.0), $16.3 \mathrm{mg} \mathrm{dm}^{-3} \mathrm{P}, 91 \mathrm{mg} \mathrm{dm}^{-3} \mathrm{~K}, 9.9 \mathrm{cmol}_{\mathrm{c}} \mathrm{dm}^{-3}$ $\mathrm{Ca}^{2+}, 4.3 \mathrm{cmol}_{\mathrm{c}} \mathrm{dm}^{-3} \mathrm{Mg}^{2+}$, and $0 \mathrm{cmol}_{\mathrm{c}} \mathrm{dm}^{-3} \mathrm{Al}^{3+}$.

The experimental design was a randomized block arranged in split plots. Each split plot consisted of six $6 \mathrm{~m}$ long rows with a spacing of $0.7 \mathrm{~m}$ between rows. In 2016/2017, 12 treatments were evaluated. Three $\mathrm{N}$ sources were assigned to the main plots: conventional urea, urea treated with nitrification inhibitor (3,4-dimethyl-1H-pyrazole phosphate, DMPP), and urea protected with sulfur resin. Four N rates were tested in the split plots: 0 (control), 50\% (140 kg ha ${ }^{-1}$ ), 100\% (280 $\mathrm{kg} \mathrm{ha}^{-1}$ ), and 150\% (420 $\mathrm{kg} \mathrm{ha}^{-1}$ ) of the $\mathrm{N}$ rate recommended by CQFS RS/SC (2016) to reach a grain yield of $18,000 \mathrm{~kg} \mathrm{ha}^{-1}$.

In 2017/2018, 16 treatments were evaluated, consisting of four $\mathrm{N}$ sources (conventional urea, urea protected with sulfur resin, urea treated with DMPP, and urea treated with the urease inhibitor $N$-butyl thiophosphoric triamide, NBPT) applied to main plots. The same four $\mathrm{N}$ rates used in the previous year were applied to the split plots. Applications of conventional urea, nitrification inhibitor-treated urea, and urease inhibitor-treated urea were performed when maize plants had six, three, and three expanded leaves, respectively, according to the development scale of Ritchie et al. (1993). Protected urea was applied on the day after sowing. The method and time of application of $\mathrm{N}$ fertilizers were in accordance with manufacturers' recommendations.

In May of each year, plots were planted with black oat (Avena strigosa) at a density of $80 \mathrm{~kg}$ seeds $\mathrm{ha}^{-1}$ as a winter cover crop. Black oat plants were desiccated with glyphosate and 2,4-D in mid-August.

Seeds of the maize hybrid P30F53VYH were sown on October 13, 2016, and October 23, 2017. Sowing was performed with manual seeders to obtain a density of 70,000 plants $\mathrm{ha}^{-1}$. Each hill was sowed with three seeds to avoid the occurrence of empty spaces. At sowing, $30 \mathrm{~kg}$ of $\mathrm{N}$ in the form of conventional urea was applied in furrow. The remaining amount of $\mathrm{N}$ fertilizer were broadcasted to the plots. Nitrogen rates and sources varied according to the experimental design. Phosphorus (Super triple, $512 \mathrm{~kg} \mathrm{ha}^{-1}$ ) and potassium (potassium chloride, 233 $\mathrm{kg} \mathrm{ha}^{-1}$ ) fertilizers were applied at sowing only. When plants had two expanded leaves, plots were manually thinned to the target population density. Weeds, pests, and diseases were chemically controlled whenever necessary to ensure that these factors did not interfere with plant development.

The following morphophysiological characteristics were assessed during maize silking (R1 stage): plant height, ear height, stem diameter, number of green leaves, number of senescent leaves, leaf area index, relative chlorophyll content, and $\mathrm{N}$ content in the flag leaf. The variables agronomic $\mathrm{N}$ use efficiency and grain $\mathrm{N}$ content were determined after harvest.

Plant height was assessed by measuring the distance from the base of the plant stem to the end 


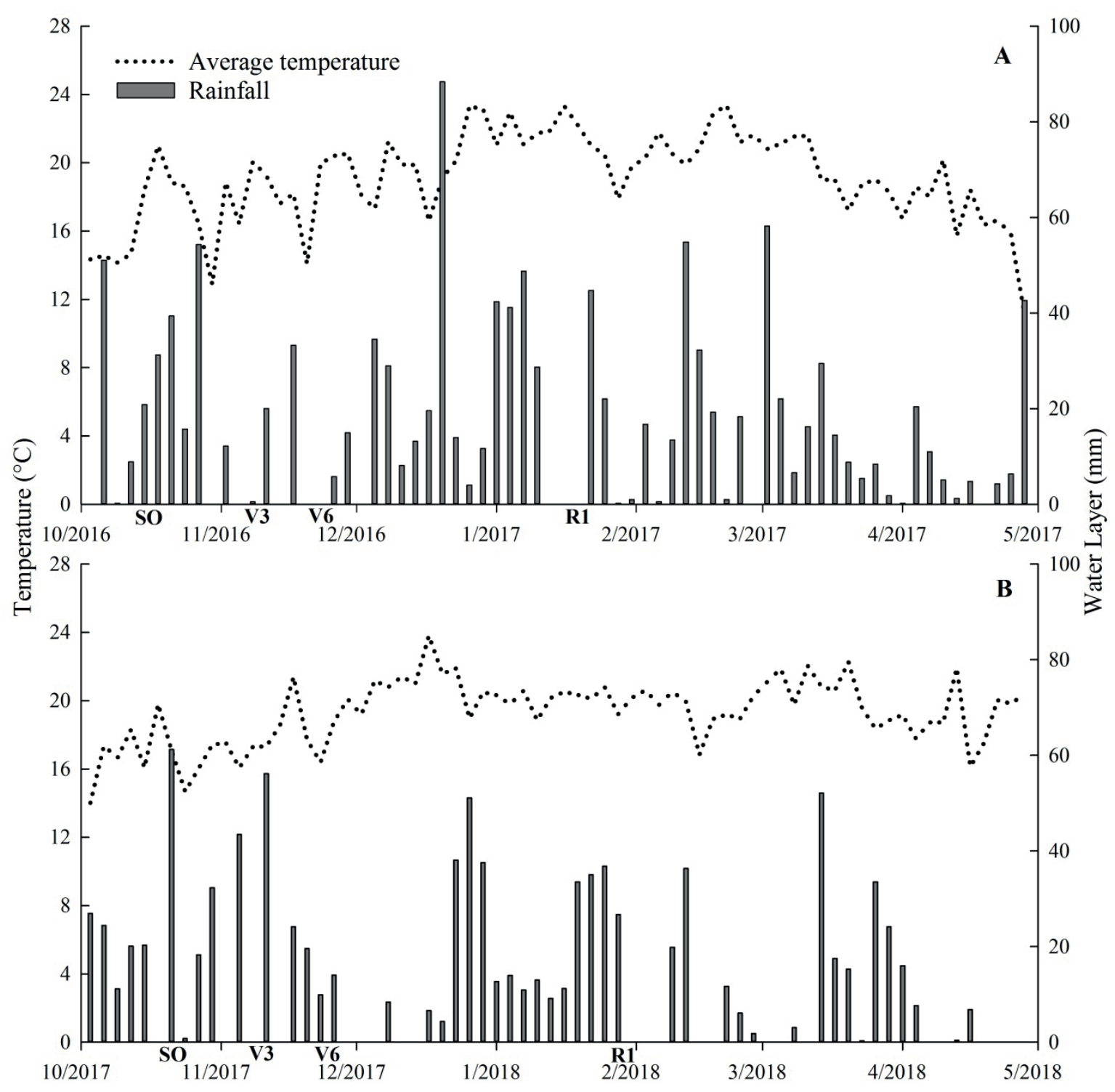

Figure 1. Average temperatures and rainfall during the (A) 2016/2017 and (B) 2017/2018 maize growing seasons in Campos Novos, Santa Catarina State, Brazil. SO, sowing; V3, three-expanded leaf stage; V6, six expanded leaf stage; R1, silking. 
of the tassel. Ear height was measured from the base of the stem to the node bearing the main ear. Stem diameter was measured at a height of $5 \mathrm{~cm}$ centimeters from ground level using a digital caliper. The numbers of green and senescent leaves were determined by counting. The leaf area index (LAI) was calculated using the equation described by Almeida et al. (2003): $\mathrm{LAI}=\mathrm{GAPP} / \mathrm{SAP}$, where GAPP is the green area per plant and ASP the soil area occupied by each plant. Plant height, ear height, number of senescent leaves, and leaf area were evaluated in five previously selected plants per experimental unit.

Agronomic N use efficiency was calculated according to the equation proposed by Fageria \& Baligar (2005): Use efficiency $=\left(\mathrm{gy}_{\mathrm{f}}-\mathrm{gy}_{\mathrm{c}}\right) /(\mathrm{Nw})$, expressed in $\mathrm{kg}$ grains $\mathrm{kg}^{-1} \mathrm{~N}$, where $\mathrm{gy}_{\mathrm{f}}$ is the grain yield of plants treated with $\mathrm{N}$ fertilizer, gy $\mathrm{c}_{\mathrm{c}}$ is the grain yield of plants not treated with $\mathrm{N}$ fertilizer, and $\mathrm{Nw}$ is the amount of $\mathrm{N}$ applied (expressed in $\mathrm{kg}$ ).

The $\mathrm{N}$ content of the flag leaf at R1 (silking) was determined according to the recommendations of Malavolta (2006). The flag leaf is the first physiologically mature leaf found opposite and below the ear. It was collected from five plants to determine this variable. $\mathrm{N}$ content was determined by the semi-micro Kjeldahl method. The relative chlorophyll content of the flag leaf was determined using a chlorophyll meter (Chlorophyllog CFL1030, Falken). The parameter was measured in five previously marked plants in each split plot at silking (R1), according to the scale proposed by Ritchie et al. (1993).

Data were subjected to analysis of variance ( $F$-test) at the 5\% significance level. When $F$-values were significant, the means of the qualitative factor $(\mathrm{N}$ source) were compared by Tukey's test and the means of the quantitative factor ( $\mathrm{N}$ rate) by regression analysis. Comparisons were made at the 5\% significance level.
Analyses were performed using Sisvar software (Ferreira, 2011).

\section{Results and discussion}

Water supply was higher in 2016/2017 growing season than in 2017/2018, there was a drought period in December, corresponding to the V9-V12 stages (Figure 1). Furthermore, water availability was lower in this growing season during grain filling. In 2016/2017, grain yield ranged from 3.2 to $15.9 \mathrm{Mg} \mathrm{ha}^{-1}$, with a mean yield of $10.5 \mathrm{Mg}$ $\mathrm{ha}^{-1}$. In 2017/2018, grain yield ranged from 2.5 to 14.2 $\mathrm{Mg} \mathrm{ha}^{-1}$, with a mean of 9.4 $\mathrm{Mg} \mathrm{ha}^{-1}$.

$\mathrm{N}$ fertilizer source significantly influenced plant height in 2016/2017 (Table 1). Protected urea provided the highest plant height $(243 \mathrm{~cm})$, differing significantly from nitrification inhibitor-treated urea, which presented the lowest plant height (236 $\mathrm{cm}$ ) (Table 1). The following year, plant height was not significantly affected by fertilizer source.

Analysis of maize ear height, stem diameter, total number of leaves, number of senescent leaves, green leaf area per plant, leaf area index, agronomic $\mathrm{N}$ use efficiency, and grain $\mathrm{N}$ content revealed that the use of stabilized and protected $\mathrm{N}$ sources did not result in differences compared with conventional urea in both growing seasons (Table 1). The similar responses of morphophysiological parameters to $\mathrm{N}$ sources indicate that maize growth and development patterns on a Red Nitosol were not influenced by $\mathrm{N}$ source. The same findings were obtained by Mota et al. (2015) in an experiment conducted on a clay soil with similar physicochemical characteristics to those of the soil used in the present study.

Plant height was affected by $\mathrm{N}$ rate. The variable increased linearly by 0.1 and 0.07

Revista Brasileira de Milho e Sorgo, v.20, e1220, 2021 DOI: https://doi.org/10.18512/rbms2021vol20e1220 
Table 1. Plant height (PH), ear height (EH), stem diameter (SD), total number of leaves (TNL), number of senescent leaves (NSL), green leaf area per plant (GLAP), leaf area index (LAI), Falker chlorophyll index (FCI), agronomic nitrogen use efficiency (ANUE), and grain nitrogen content (GNC) of maize as a function of nitrogen sources in 2016/2017 and 2017/2018 seasons.

\begin{tabular}{|c|c|c|c|c|c|c|c|c|c|c|}
\hline \multicolumn{11}{|c|}{$2016 / 2017$} \\
\hline $\begin{array}{c}\mathrm{N} \\
\text { source }\end{array}$ & $\begin{array}{l}\mathrm{PH} \\
(\mathrm{cm})\end{array}$ & $\begin{array}{l}\mathrm{EH} \\
(\mathrm{cm})\end{array}$ & $\begin{array}{c}\mathrm{SD} \\
(\mathrm{mm})\end{array}$ & TNL & NSL & $\begin{array}{l}\text { GLAP } \\
\left(\mathrm{cm}^{2}\right)\end{array}$ & LAI & FCI & $\begin{array}{l}\text { ANUE (kg } \\
\left.\text { grain } \mathrm{kg}^{-1} \mathrm{~N}\right)\end{array}$ & $\begin{array}{l}\text { GNC } \\
(\%)\end{array}$ \\
\hline C-UR & $241 a b$ & $107^{\mathrm{ns}}$ & $22.27^{\mathrm{ns}}$ & $19.68^{\mathrm{ns}}$ & $8.08^{\mathrm{ns}}$ & $5696^{\text {ns }}$ & $3.99^{\mathrm{ns}}$ & 51.02 & $30.67^{\mathrm{ns}}$ & $1.15^{\mathrm{ns}}$ \\
\hline P-UR & $243 b$ & $109^{\mathrm{ns}}$ & $22.11^{\mathrm{ns}}$ & $19.48^{\mathrm{ns}}$ & $8.67^{\mathrm{ns}}$ & $5613^{\mathrm{ns}}$ & $3.93^{\mathrm{ns}}$ & 48.70 & $25.58^{\mathrm{ns}}$ & $1.18^{\mathrm{ns}}$ \\
\hline NI-UR & $236 a$ & $104^{\mathrm{ns}}$ & $21.48^{\mathrm{ns}}$ & $19.85^{\mathrm{ns}}$ & $8.48^{\mathrm{ns}}$ & $5584^{\mathrm{ns}}$ & $3.91^{\mathrm{ns}}$ & 49.85 & $28.18^{\mathrm{ns}}$ & $1.19^{\mathrm{ns}}$ \\
\hline CV (\%) & 5.9 & 5.9 & 8.3 & 2.05 & 6.73 & 9.91 & 10.2 & 4.77 & 23.78 & 4.85 \\
\hline \multicolumn{11}{|c|}{$2017 / 2018$} \\
\hline $\begin{array}{c}\mathrm{N} \\
\text { source }\end{array}$ & $\begin{array}{l}\mathrm{PH} \\
(\mathrm{cm})\end{array}$ & $\begin{array}{l}\mathrm{EH} \\
(\mathrm{cm})\end{array}$ & $\begin{array}{c}\mathrm{SD} \\
(\mathrm{mm})\end{array}$ & TNL & NSL & $\begin{array}{l}\text { GLAP } \\
\left(\mathrm{cm}^{2}\right)\end{array}$ & LAI & FCI & $\begin{array}{c}\text { ANUE (kg } \\
\left.\text { grain } \mathrm{kg}^{-1} \mathrm{~N}\right)\end{array}$ & $\begin{array}{l}\text { GNC } \\
(\%)\end{array}$ \\
\hline C-UR & $240^{\mathrm{ns}}$ & $109^{\mathrm{ns}}$ & $19.33^{\mathrm{ns}}$ & $20.68^{\mathrm{ns}}$ & $7.64^{\mathrm{ns}}$ & $4959^{\text {ns }}$ & $3.47^{\mathrm{ns}}$ & $57.22^{\mathrm{ns}}$ & $18.34^{\mathrm{ns}}$ & $0.91^{\mathrm{ns}}$ \\
\hline P-UR & $243^{\mathrm{ns}}$ & $109^{\mathrm{ns}}$ & $20.53^{\mathrm{ns}}$ & $21.12^{\mathrm{ns}}$ & $7.92^{\mathrm{ns}}$ & $5162^{\text {ns }}$ & $3.61^{\mathrm{ns}}$ & $55.45^{\mathrm{ns}}$ & $19.07^{\mathrm{ns}}$ & $0.68^{\mathrm{ns}}$ \\
\hline NI-UR & $245^{\mathrm{ns}}$ & $110^{\mathrm{ns}}$ & $20.74^{\mathrm{ns}}$ & $20.75^{\mathrm{ns}}$ & $7.62^{\mathrm{ns}}$ & $5467^{\mathrm{ns}}$ & $3.83^{\mathrm{ns}}$ & $59.71^{\mathrm{ns}}$ & $26.17^{\mathrm{ns}}$ & $0.97^{\mathrm{ns}}$ \\
\hline UI-UR & $248^{\mathrm{ns}}$ & $112^{\mathrm{ns}}$ & $20.18^{\mathrm{ns}}$ & $20.62^{\mathrm{ns}}$ & $7.50^{\mathrm{ns}}$ & $5281^{\text {ns }}$ & $3.70^{\mathrm{ns}}$ & $60.52^{\mathrm{ns}}$ & $17.59^{\mathrm{ns}}$ & $0.96^{\mathrm{ns}}$ \\
\hline CV (\%) & 18.16 & 19.79 & 6.3 & 4.54 & 8.60 & 14.68 & 14.68 & 22.09 & 48.16 & 13.36 \\
\hline
\end{tabular}

Results are the mean of four nitrogen doses.

Means within a column followed by the same lowercase letter are not significantly different by Tukey's test $(p<0.05)$.

${ }^{\text {ns }}$ Differences between means in a column are not significant at $p<0.05$.

C-UR, conventional urea; P-UR, protected urea; NI-UR (DMPP), nitrification inhibitor-treated urea; UI-UR (NBPT), urease inhibitortreated urea; $\mathrm{CV}$, coefficient of variation.

cm per kilogram of $\mathrm{N}$ applied in 2016/2017 and 2017/2018, respectively (Figure 2A and B). These increments resulted in plant heights of 254 and $255 \mathrm{~cm}$ at the highest $\mathrm{N}$ rate in 2016/2017 and 2017/2018, respectively. An increase in plant height with increasing $\mathrm{N}$ rate was also reported by Coelho et al. (2020), Gazola et al. (2014), Goes et al. (2013), and Petter et al. (2016). Such effect can be explained by the fact that $\mathrm{N}$ acts directly on the shoot apical meristem of maize, stimulating cell division and promoting longitudinal growth of the stem (Sangoi et al., 2016).

Similar to plant height, ear height and stem diameter differed significantly according to $\mathrm{N}$ rate. Ear height showed an increasing linear trend as a function of the $\mathrm{N}$ rate in both growing seasons. This 
result is in agreement with the findings of Goes et al. (2013) and Coelho et al. (2019). For each kg of increase in $\mathrm{N}$ rate, up to the rate of $420 \mathrm{~kg}$ ha- $1 \mathrm{~N}$, there was a mean increase of $0.25 \mathrm{~cm}$ and $0.11 \mathrm{~cm}$ in ear height in 2016/2017 and 2017/2018, respectively (Figure 2C and D). The mean ear height was 120 and $116 \mathrm{~cm}$ in 2016/2017 and 2017/2018, respectively, with a reduction of $3.3 \%$ from the first to the second year of cultivation. Stem diameter also showed a linear increasing trend of 0.03 and $0.01 \mathrm{~mm}$ in 2016/2017 and 2017/2018, respectively, for every 1 $\mathrm{kg}$ increase in $\mathrm{N}$ rate, corroborating the data reported by Coelho et al. (2019), Gazola et al. (2014), Kappes et al. (2014), and Goes et al. (2013).

Lodged or broken plants were not observed in the first growing season. In the second year, 5.46\% of plants in the control group (without $\mathrm{N}$ fertilization) were lodged or broken, differing significantly from groups treated with 140,280 , or $420 \mathrm{~kg} \mathrm{ha}^{-1} \mathrm{~N}$, which showed $1.18,1.28$, and $1.87 \%$ of lodged or broken plants, respectively (Figure 3 ). The lowest lodging percentage was estimated to be achieved with an $\mathrm{N}$ dose of $283 \mathrm{~kg} \mathrm{ha}^{-1}$. $\mathrm{N}$ deficiency reduces stem diameter and storage reserves, favoring lodging and rupture of plants before harvest (Coelho et al., 2019).

The quadratic relationship between the percentage of lodged and broken plants and $\mathrm{N}$ rates (Figure 3) can be explained by the height and diameter growth dynamics of maize stalks in response to increasing $\mathrm{N}$ doses (Figure 2). Plants treated with high $\mathrm{N}$ rates have higher ear heights than plants treated with low $\mathrm{N}$ doses (Coelho et al., 2019). Under these condition, maize ears are more prone to the inverted pendulum effect, which increases tension on the base of the stem and roots. This can make plants more susceptible to lodging and breaking. On the other hand, an increase in $\mathrm{N}$ dose is known to increase stem diameter (Coelho et al., 2019), improving plant resistance. Thicker culms are also advantageous because they have greater capacity to accumulate photoassimilates, which contributes to grain filling (Kappes et al., 2014). However, as noted by Coelho et al. (2019), at supraoptimal doses ( $\left.>283 \mathrm{~kg} \mathrm{ha}^{-1} \mathrm{~N}\right), \mathrm{N}$ fertilization is no longer advantageous, as it promotes lodging and rupture of maize stems.

Total numberofleaves per plant was influenced by $\mathrm{N}$ rate in the first growing season (Figure 4A). The variable increased from 19.4 (control) to 20 (420 kg $\mathrm{ha}^{-1} \mathrm{~N}$ ). In the second year, there were no differences between $\mathrm{N}$ rates and plants produced on average 20.8 leaves (Figure 4B). Number of senescent leaves was also significantly influenced by $\mathrm{N}$ rate. There was a linear reduction trend with increasing $\mathrm{N}$ dose (Figure $4 \mathrm{C}$ and $\mathrm{D}$ ). $\mathrm{N}$ has an important impact on the number of senescent leaves, as it affects the longevity of older leaves (Coelho et al., 2020; França et al., 2011). $\mathrm{N}$-deficient plants remobilize this element from older and basal leaves to younger leaves. This behavior is a response to the high demand for $\mathrm{N}$ of expanding leaves, given that $\mathrm{N}$ is a component of proteins such as chlorophyll, which play a major role in photosynthesis (Sangoi et al., 2016). With the maintenance of total leaf number and the reduction in number of senescent leaves with increasing $\mathrm{N}$ rates, there was an increase in green leaf area per plant (Figure 4E and F).

Leaf area index increased linearly as a function of increasing $\mathrm{N}$ rates. The maximum leaf area indices estimated by equations were 5.3 and 4.1 in 2016/2017 and 2017/2018, respectively (Figure 4G and $\mathrm{H}$ ). In the first growing season, each increase of $1 \mathrm{~kg}$ in $\mathrm{N}$ rate resulted in a 0.02 increase in leaf area index. In 2017/2018, the increase was of 0.006 . This variable increased because the total number of leaves remained the same between treatments (Figure 4A 


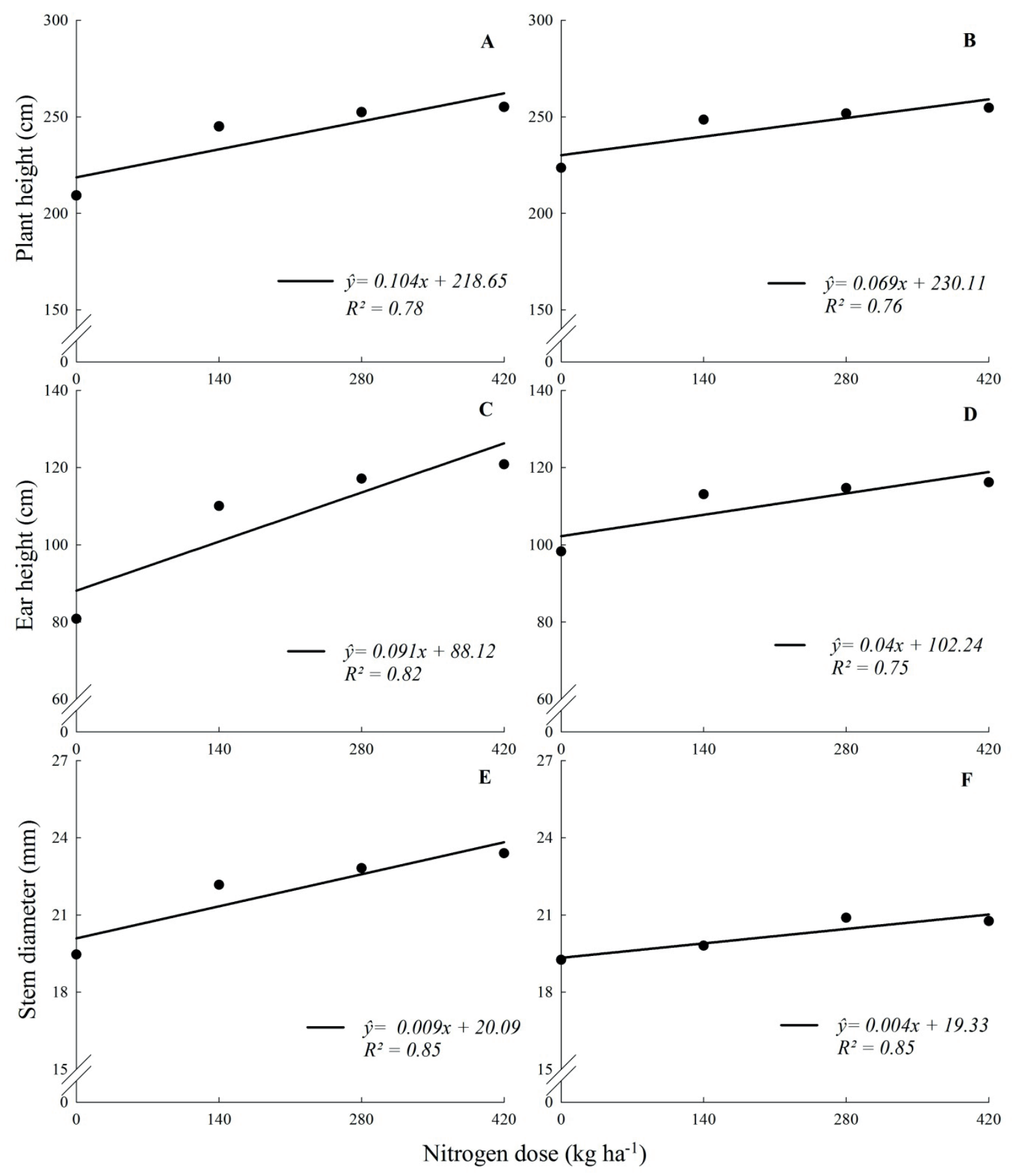

Figure 2. Plant height in (A) 2016/2017 and (B) 2017/2018, ear height in (C) 2016/2017 and (D) 2017/2018, and stem diameter in (E) 2016/2017 and (F) 2017/2018 of maize crop as a function of nitrogen rates. Results are the mean of four nitrogen fertilizer sources. Campos Novos, Santa Catarina State, Brazil. 


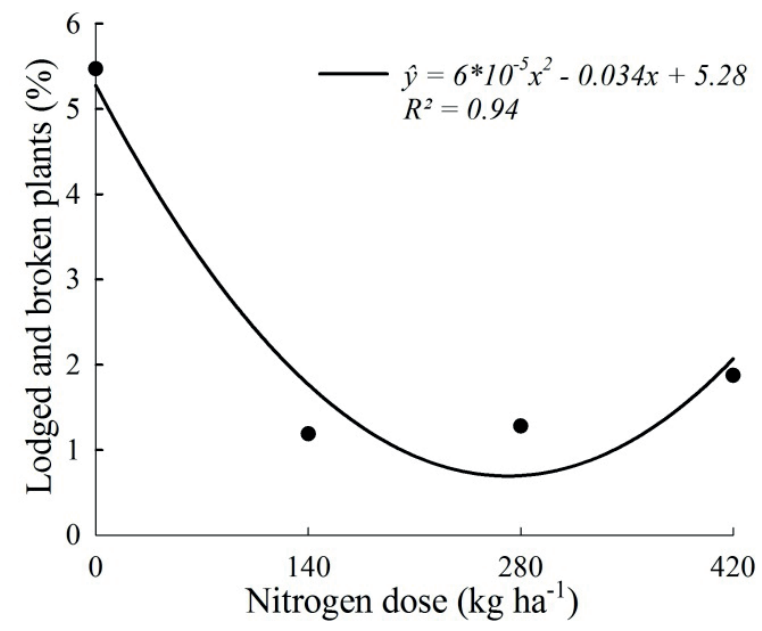

Figure 3. Lodging and breakage percentage of maize crops as a function of nitrogen rates in 2017/2018 growing season. Results are the mean of four nitrogen fertilizer sources. Campos Novos, Santa Catarina State, Brazil.

and $\mathrm{B})$, but the number of senescent leaves decreased (Figure 4C and D). Coelho et al. (2020) observed that the use of increasing $\mathrm{N}$ doses leads to an increase in leaf area index until silking and contributes to the maintenance of leaf area during grain filling, which may positively impact grain yield.

The Falker chlorophyll index increased quadratically as a function of increasing $\mathrm{N}$ doses in both growing seasons (Figure 5A and B). In 2016/2017, N rate and source interaction effects were significant. At 150 $\mathrm{kg} \mathrm{ha}^{-1} \mathrm{~N}$, protected urea promoted lower chlorophyll content than the other $\mathrm{N}$ sources, a behavior not observed at other doses. In 2016/2017, the maximum chlorophyll content in plants that received nitrification inhibitor-treated urea or conventional urea was reached at rates of 380 and $290 \mathrm{~kg} \mathrm{ha}^{-1} \mathrm{~N}$, respectively. For protected urea, the tested doses (up to $420 \mathrm{~kg} \mathrm{ha}^{-1} \mathrm{~N}$ ) were not sufficient to reach the maximum chlorophyll content. In 2017/2018, the maximum chlorophyll content was reached at $313 \mathrm{~kg} \mathrm{ha}^{-1} \mathrm{~N}$, regardless of $\mathrm{N}$ source. Increasing $\mathrm{N}$ rates improves $\mathrm{N}$ availability and assimilation, thereby enhancing the amount of chlorophyll in leaves (Biscaro et al., 2012). Overall, the Falker chlorophyll index was higher in the second than in the growing season. This result is probably due to the drought that occurred between V8 and V12 in the second year. This phase presents intense foliar expansion (Sangoi et al., 2010). Water restriction led to a reduction in green leaf area per plant (Figure 4E and F), promoting chlorophyll concentration in leaves. A similar behavior was described by Shao et al. (2008). It is possible that the need for higher rates of protected urea to achieve the same chlorophyll content as that showed by other $\mathrm{N}$ sources is an indication of the need for greater water supply. Solubilization of $\mathrm{N}$ in soil is more dependent on water supply when protected urea is used as $\mathrm{N}$ source (Li et al., 2019). 


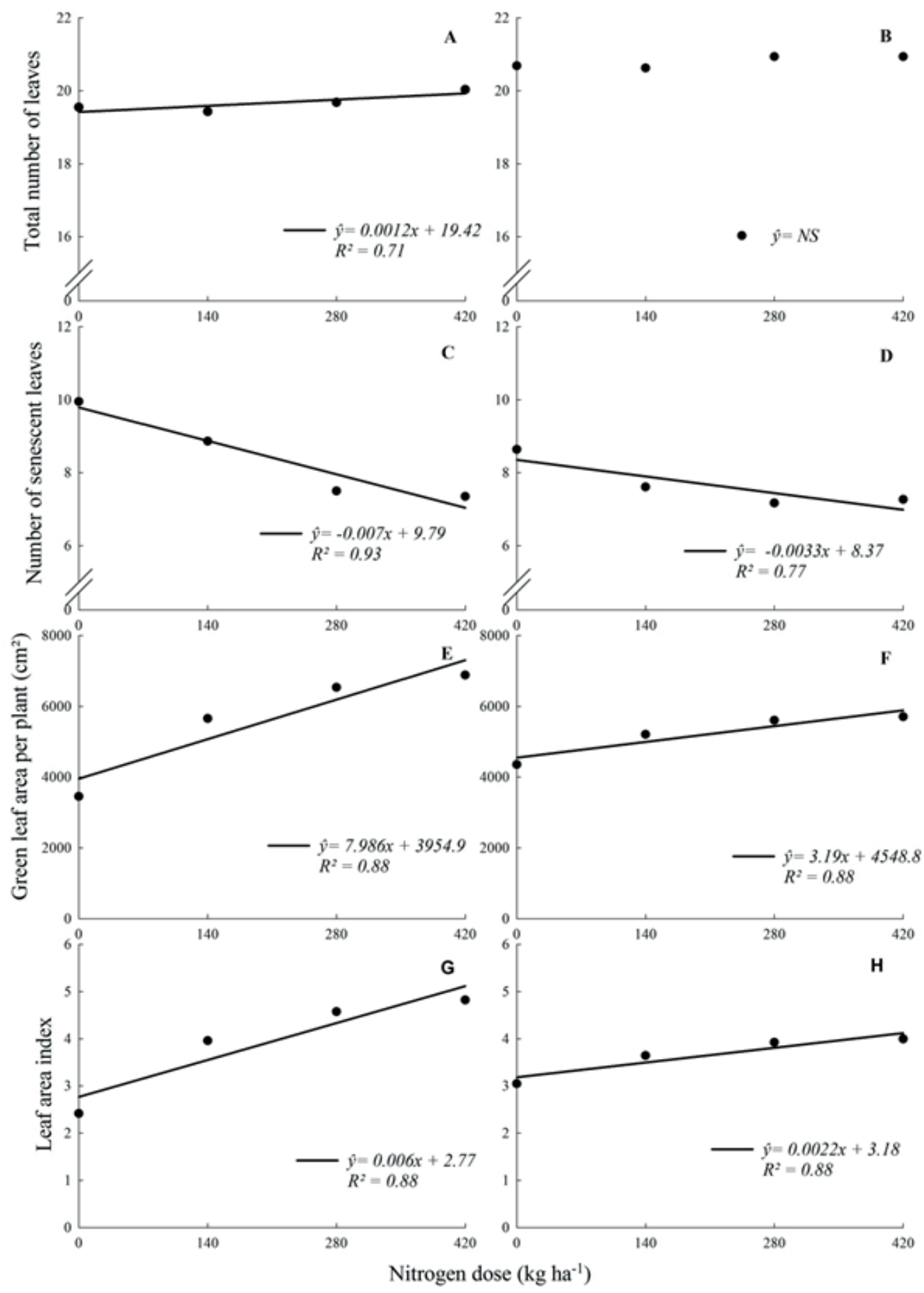

Figure 4. Total number of leaves in (A) 2016/2017 and (B) 2017/2018, number of senescent leaves in (C) 2016/2017 and (D) 2017/2018, green leaf area per plant in (E) 2016/2017 and (F) 2017/2018, and leaf area index in (G) 2016/2017 and (H) 2017/2018 of maize as a function of nitrogen rates. Results are the mean of four nitrogen fertilizer sources. NS, not significant at $p<0.05$. Campos Novos, Santa Catarina State, Brazil. 


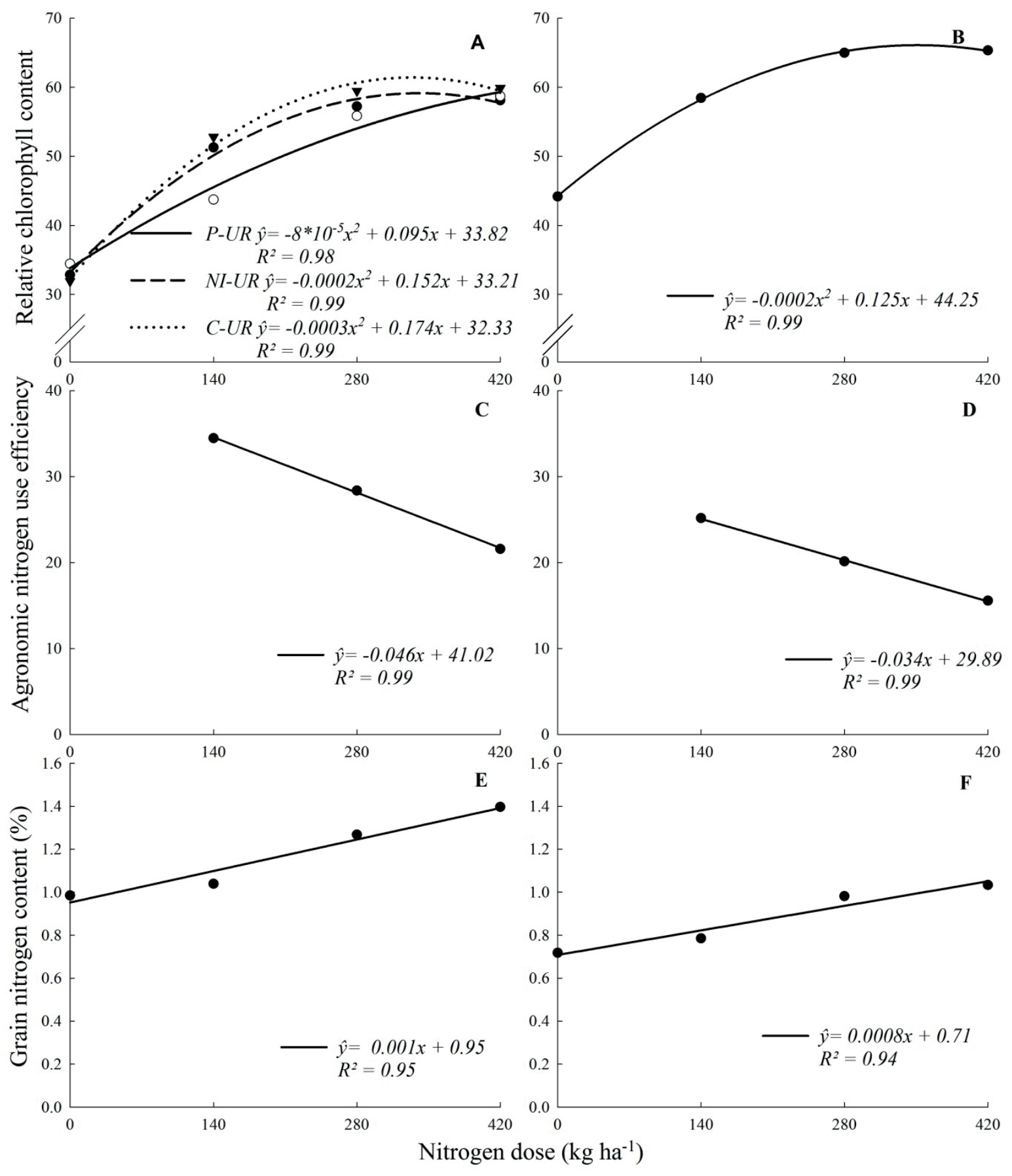

Figure 5. Falker chlorophyll index in (A) 2016/2017 and (B) 2017/2018, agronomic nitrogen use efficiency in (C) 2016/2017 and (D) 2017/2018, and grain nitrogen content in (E) 2016/2017 and (F) 2017/2018 of maize as a function of nitrogen rates. Results are the mean of four nitrogen fertilizer sources. C-UR, conventional urea; P-UR, protected urea; NI-UR (DMPP), nitrification inhibitor-treated urea; UI-UR (NBPT), urease inhibitortreated urea. Campos Novos, Santa Catarina State, Brazil. 
Agronomic $\mathrm{N}$ use efficiency did not differ between $\mathrm{N}$ sources in both growing seasons (Table 1). $\mathrm{N}$ losses via nitrate leaching, ammonia volatilization, and $\mathrm{N}_{2}$ and $\mathrm{N}_{2} \mathrm{O}$ emission can be minimized by using $\mathrm{N}$ sources containing urease and nitrification inhibitors or protected urea, which increase the persistence of $\mathrm{N}$ in soil (Dall'Orsoletta et al., 2017; Scheer et al., 2014). However, greater persistence of $\mathrm{N}$ in soil does not necessarily mean that the element will be used more efficiently by plants. The data reported in Table 1 corroborate this statement.

The $\mathrm{N}$ absorption capacity of maize is related to two factors. The first is the competence of the root system in extracting $\mathrm{N}$ from soil. This ability is directly linked to the number of roots and final root size, especially during the vegetative phase (V6 to VT, tasseling), a period where the demand for $\mathrm{N}$ is higher (Sangoi et al., 2016). The second factor is the ability of $\mathrm{N}$ to pass through the plasma membrane of root cells. The plasma contains $\mathrm{N}$ receptors that regulate the entry of $\mathrm{NO}_{3}^{-}$, mainly by differences in concentrations between intracellular and extracellular media. According to Moll et al. (1982), nutrient efficiency depends on absorption efficiency, measured by the relationship between total amount of nutrient extracted by plants and total amount of nutrient available in soil, and use efficiency, calculated as the ratio of grain or shoot weight to the total amount of nutrient extracted by plants. Thus, gains in nutrient efficiency can be achieved by increasing absorption efficiency or utilization efficiency. Environmental factors such as water deficit can impact both $\mathrm{N}$ absorption and utilization efficiency (Ullah et al., 2019).

There was a linear increase in grain $\mathrm{N}$ content with increasing $\mathrm{N}$ rate (Figure $5 \mathrm{E}$ and $\mathrm{F}$ ). Each $1 \mathrm{~kg}$ increase in $\mathrm{N}$ rate provided an increase of 0.03 and $0.02 \mathrm{~g} \mathrm{~kg}^{-1} \mathrm{~N}$ in grains in 2016/2017 and 2017/2018, respectively. Such finding may indicate increased protein content in grains (Sriperm et al., 2011). On the other hand, agronomic $\mathrm{N}$ use efficiency decreased linearly with increasing $\mathrm{N}$ dose (Figure $5 \mathrm{C}$ and $\mathrm{D}$ ), suggesting that the ability of maize to convert $\mathrm{N}$ fertilizer into grains decreases with increasing $\mathrm{N}$ availability in soil. Similar results were obtained by Mota et al. (2015) and Coelho et al. (2022) when evaluating the effects of $\mathrm{N}$ doses in a Red Nitosol in the Catarinense Plateau.

The use of increasing $\mathrm{N}$ rates leads to an increase in leaf area index, chlorophyll content in the flag leaf, grain production, and grain $\mathrm{N}$ content in maize. However, the higher the $\mathrm{N}$ dose, the lower the agronomic $\mathrm{N}$ use efficiency, which may lead to negative economic and environmental impacts. There is a need for higher doses of protected urea to achieve similar levels of chlorophyll in R1 compared with other $\mathrm{N}$ sources in the year with reduced water supply. This find suggests that the protected urea depends on adequate water supply to release $\mathrm{N}$.

It was expected that the use of sources that minimize $\mathrm{N}$ losses would modify the response of morphophysiological parameters to increasing $\mathrm{N}$ rates, thus enhance the $\mathrm{N}$ use efficiency by maize However, these hypotheses were not confirmed in the present study. On a clay Red Nitosol, the response of morphophysiological parameters to $\mathrm{N}$ dose is little affected by $\mathrm{N}$ fertilizer source. Furthermore, stabilized and protected $\mathrm{N}$ sources have higher costs and do not increase $\mathrm{N}$ use efficiency. 


\section{Conclusions}

The use of stabilized or protected $\mathrm{N}$ fertilizer sources does not change maize ear height, leaf area index during flowering, stem diameter, or grain $\mathrm{N}$ content compared with the use of conventional urea.

Regardless of the $\mathrm{N}$ source, increasing $\mathrm{N}$ rates enhance plant height, ear height, stem diameter, and leaf area index during flowering and reduce agronomic $\mathrm{N}$ use efficiency.

The use of stabilized or protected $\mathrm{N}$ fertilizers does not increase the $\mathrm{N}$ use efficiency of maize grown on a clay Red Nitosol compared with conventional urea.

\section{References}

ALMEIDA, M. L. D.; SANGOI, L.; NAVA, I. C.; GALIO, J.; TRENTIN, P. S.; RAMPAZZO, C. Crescimento inicial de milho e sua relação com o rendimento de grãos. Ciência Rural, v. 33, n. 2, p. 189-194, 2003. DOI: https://doi.org/10.1590/S010384782003000200002 .

BISCARO, G. A., DA SILVA, J. A., DOS SANTOS ZOMERFELD, P., DE ARAUJO MOTOMIYA, A. V., GOMES, E. P., GIACON, G. M. Chicory yield under levels of nitrogen fertirrigation and position of drip hoses on the ridge. Ciência Rural, v. 42, n. 10, p. 1811-1818, 2012. DOI: https://doi.org/10.1590/ S0103-84782012005000075.

CANTARELLA, H., OTTO, R., SOARES, J.R., SILVA, A.G.b. Agronomic efficiency of NBPT as a urease inhibitor: A review. Journal of Advanced Research, v. 13, p. 19-27, 2018. DOI: 10.1016/j. jare.2018.05.008
COELHO, A. E., SANGOI, L., CASA, R. T., KUNESKI, H. F., PANISON, F., LEOLATO, L. S., DURLI, M. M., BERGHETTI, J. Sanidade de híbridos de milho em função da época de semeadura, doses de $\mathrm{N}$ em áreas com e sem rotação de culturas. Colloquium Agrariae, v. 15, n. 2, p. 101-113, 2019. DOI: 10.5747/ca.2019.v15.n2.a289

COELHO, A. E., SANGOI, L., BALBINOT JUNIOR, A. A., FIOREZE, S. L., BERGHETTI, J., KUNESKI, H. F., LEOLATO, L. S., MARTINS JÚNIOR, M. C. Growth patterns and yield of maize hybrids as affected by nitrogen rates and sowing dates in southern brazil. Crop and Pasture Science, 2020. DOI: https://doi.org/10.1071/CP20077

COELHO, A. E., SANGOI, L., BALBINOT JUNIOR, A. A., KUNESKI, H. F., MARTINS JÚNIOR, M. C. Nitrogen use efficiency and grain yield of corn hybrids as affected by nitrogen rates and sowing dates in subtropical environment. Revista Brasileira de Ciência do Solo, v. 46, e0210087, 2022. DOI: http:// dx.doi.org/10.36783/18069657rbcs20210087

COMISSÃO DE QUÍMICA E FERTILIDADE DO SOLO, RS/SC. Manual de calagem e adubação para os estados do Rio Grande do Sul e de Santa Catarina. Porto Alegre: Sociedade Brasileira de Ciência do Solo/Núcleo Regional Sul, 2016. 376 p.

DALL'ORSOLETTA, D. J., RAUBER, L. P., SCHMITT, D. E., GATIBONI, L. C., ORSOLIN, J. Urea coated with poultry litter as an option in the control of nitrogen losses. Revista Brasileira de Engenharia Agrícola e Ambiental, v. 21, n. 6, p. 398-403, 2017. DOI: https://doi.org/10.1590/18071929/agriambi.v21n6p398-403. 
DARYANTO, S., WANG, L., GILHOOLY III, W. P., JACINTHE, P. A. Nitrogen preference across generations under changing ammonium nitrate ratios. Journal of Plant Ecology, v. 12, n. 2, p. 235-244, 2019. DOI: https://doi.org/10.1093/jpe/rty014.

DE NOTARIS, C., RASMUSSEN, J., SØRENSEN, P., OLESEN, J. E. Nitrogen leaching: A crop rotation perspective on the effect of $\mathrm{N}$ surplus, field management and use of catch crops. Agriculture, Ecosystems \& Environment, v. 255, p. 1-11, 2018. DOI: https://doi.org/10.1016/j.agee.2017.12.009.

FAGERIA, N. K.; BALIGAR, V. C. Enhancing nitrogen use efficiency in crop plants. Advances in Agronomy, v.88, p.97-185, 2005. DOI: https://doi. org/10.1016/S0065-2113(05)88004-6.

FERREIRA, D.F. Sisvar: A computer statistical analysis system. Ciência e Agrotecnologia, v.35, n.6, p.1039-1042, 2011. DOI: https://doi.org/10.1590/ S1413-70542011000600001.

FRANÇA, S., MIELNICZUK, J., ROSA, L. M. G., BERGAMASCHI, H., BERGONCI, J. I. Nitrogênio disponível ao milho: Crescimento, absorção e rendimento de grãos. Revista Brasileira de Engenharia Agrícola Ambiental, v.15, n.11, p.1143-1151, 2011. DOI: https://doi.org/10.1590/ S1415-43662011001100006.
GAZOLA, D., ZUCARELI, C., SILVA, R. R., FONSECA, I. C. D. B. Aplicação foliar de aminoácidos e adubação nitrogenada de cobertura na cultura do milho safrinha. Revista Brasileira de Engenharia Agrícola Ambiental, v.18, n.7, p.700707, 2014. DOI: https://doi.org/10.1590/S141543662014000700005.

GOES, R. J., RODRIGUES, R. A. F., TAKASU, A. T., ARF, O. Características agronômicas e produtividade do milho sob fontes e doses de nitrogênio em cobertura no inverno. Revista Brasileira de Milho e Sorgo, v.12, n.3, p. 250-259, 2013. DOI: https://doi. org/10.18512/1980-6477/rbms.v12n3p250-259.

KAPPES, C., ARF, O., DAL BEM, E. A., PORTUGAL, J. R., GONZAGA, A. R. Manejo do nitrogênio em cobertura na cultura do milho em sistema de plantio direto. Revista Brasileira de Milho e Sorgo, v.13, n.2, p. 201-217, 2014. DOI: https://doi. org/10.18512/1980-6477/rbms.v13n2p201-217.

LANA, R. M. Q., PEREIRA, V. J., LEITE, C. N., TEIXEIRA, G. M., DA SILVA GOMES, J., DE CAMARGO, R. NBPT (urease inhibitor) in the dynamics of ammonia volatilization. Revista Brasileira de Ciências Agrárias, v.13, n.2, e5538, 2018. DOI: https://doi.org/10.5039/agraria. v13i2a5538.

LI, G., ZHAO, B., DONG, S., ZHANG, J., LIU, P., REN, B., LU, D., LU, W. Morphological and Physiological Characteristics of Maize Roots in Response to Controlled-Release Urea under Different Soil Moisture Conditions. Agronomy Journal, v. 111, n. 4, p. 1849-1864, 2019. DOI: https://doi. org/10.2134/agronj2018.08.0508. 
MALAVOLTA, E. Manual de nutrição mineral de plantas. São Paulo: Agronômica Ceres, 2006. 638 p.

MIGLIORATI, M. D. A., SCHEER, C., GRACE, P. R., ROWLINGS, D. W., BELL, M., MCGREE, J. Influence of different nitrogen rates and DMPP nitrification inhibitor on annual $\mathrm{N}_{2} \mathrm{O}$ emissions from a subtropical wheat-maize cropping system. Agriculture, Ecosystems and Environment v. 186, p.33-43, 2014. DOI: https://doi.org/10.1016/j. agee.2014.01.016.

MOLL, R., KAMPRATH, E., JACKSON, W. Analysis and interpretation of factors which contribute to efficiency of nitrogen utilization. Agronomy Journal. v. 74, n. 3, p. 562-564, 1982. DOI: https:// doi.org/10.2134/agronj1982.0002196200740003003 $7 \mathrm{x}$.

MOTA, M. R., SANGOI, L., SCHENATTO, D. E., GIORDANI, W., BONIATTI, C. M., DALL'IGNA, L. Fontes estabilizadas de nitrogênio como alternativa para aumentar o rendimento de grãos e a eficiência agronômica de uso do nitrogênio pelo milho. Revista Brasileira de Ciência do Solo, v. 39, n. 2, p. 512522, 2015. DOI: https://doi.org/10.1590/01000683rb cs20140308.

PETTER, F. A., ANDRADE, F. R., ZUFFO, A. M., DE SOUSA MONTEIRO, M. M., PACHECO, L. P., DE ALMEIDA, F. A. Doses e épocas de aplicação de potássio no desempenho agronômico do milho no cerrado piauiense. Comunicata Scientiae, v. 7, n. 3, p. 372-382, 2016. DOI: https://doi.org/10.14295/ cs.v7i3.1218.
PRANDO, A. M., ZUCARELI, C., FRONZA, V., OLIVEIRA, E. A. D. P., PANOFF, B. Formas de ureia e doses de nitrogênio em cobertura na qualidade fisiológica de sementes de trigo. Revista Brasileira de Sementes, v. 34, n. 2, p. 272-279, 2012. DOI: https://doi.org/10.1590/S0101-31222012000200012.

RITCHIE, S. W.; BENSON, G.O.; LUPKES, S. J. How a corn plant develops? Ames: Iowa State University of Science and Technology, 1993. 21 p.

SANGOI, L.; SILVA, P. R. F.; ARGENTA, G.; RAMBO, L. Ecofisiologia da cultura do milho para altos rendimentos. Lages: Graphel, 2010. v. 1. 84 p.

SANGOI, L.; SILVA, P. R. F.; PAGLIARINI, N. H. F. Estratégias de manejo da adubação nitrogenada em milho na região sul do Brasil. Lages: Graphel, 2016. 119 p.

SCHEER, C., ROWLINGS, D. W., FIRREL, M., DEUTER, P., MORRIS, S., GRACE, P. R. Impact of nitrification inhibitor (DMPP) on soil nitrous oxide emissions from an intensive broccoli production system in sub-tropical Australia. Soil Biology \& Biochemistry v.77, p.243-251, 2014. DOI: https:// doi.org/10.1016/j.soilbio.2014.07.006.

SHAO, H. B., CHU, L. Y., JALEEL, C. A., ZHAO, C. $X$. Water-deficit stress induced anatomical changes in higher plants. Comptes Rendus Biologies, v. 331, n. 3, p. 215-225, 2008. DOI: https://doi.org/10.1016/j. crvi.2008.01.002. 
SRIPERM, N.; PESTI, G. M.; TILLMAN, P. B. ULLAH, H.; SANTIAGO-ARENAS, R.; FERDOUS, Evaluation of the fixed nitrogen-to-protein (N: P) Z.; ATTIA, A.; DATTA, A. Improving water use conversion factor (6.25) versus ingredient specific efficiency, nitrogen use efficiency, and radiation use $\mathrm{N}$ : P conversion factors in feedstuffs. Journal of the efficiency in field crops under drought stress: a review. Science of Food and Agriculture, v. 91, n. 7, p. 1182- Advances in Agronomy, v. 156, p. 109-157, 2019. 1186, 2011. DOI: https://doi.org/10.1002/jsfa.4292. DOI: https://doi.org/10.1016/bs.agron.2019.02.002. 